DOI 10.37882/2223-2982.2020.06-2.35

\title{
НАЧАЛЬНЫЙ ЭТАП ФОРМИРОВАНИЯ КИТАЙСКОГО ЯЗЫКОЗНАНИЯ
}

\section{THE FIRST STAGE OF FORMATION OF CHINESE LINGUISTICS}

Tsi Yalun

Summary: The study of reasons of Chinese linguistics' fomation and the formation of its stages are one of the highest priorities in traditional language studies for both Chinese and Russian scholars. The article considers two periods, during which Chinese linguistics was formed at the initial stage.

Keywords: pre-Qin period, Han Dynasty, the formation of Chinese linguistics, Chinese linguistics.

\author{
Ци Ялунь \\ Аспирант, Московский государственный университет \\ имени М.В. Ломоносова \\ qiyalun096@gmail.com
}

Аннотация: Изучение причин возникновения китайского языкознания, формирование его этапов являются одними из наиболее приоритетных направлений в традиционных языковых исследованиях как для китайских, так и для российских учёных. В статье рассматривается две эпохи, в течение которых формировалось китайское языкознание на начальном этапе.

Ключевые слова: доциньская эпоха, ханьская эпоха, формирование китайского языкознания, китайское языкознание.
Л ингвистика уходит далеко в историю. Китайцы начали самостоятельно ориентироваться в лингвистике более 2 тысяч лет назад. В эпоху древнего Китая не было такого термина как"лингвистика", а только было такое понятие, как "Сяосюэ" (“小学", в котором первый иероглиф обозначает "маленький", второй иероглиф обозначает "учение", целиком это старая китайская филология), которое почти совпадает с понятием лингвистика в данный период. Сяосюэ - это наука о письменности, можно сказать, что до опиумной войны (1840-1842 г.) китайское языкознание представляет собой предмет, изучающий письменность.

Необходимо упомянуть 2 периода для исследования формирования китайского языкознания: первый период - доциньская эпоха (до 3 в. до н.э.), в которую пустил первый росток китайского языкознания; второй период - династия Хань (3 в. до н.э. - начало 3 в. н.э.), в эпоху которого было создано Сюньгусюэ (训诂学, толкование древней литературы).

\section{Языковые исследования в Аошиньскую эпоху}

Никаких профессиональных лингвистов в течение этого периода еще не было, и лингвистика не являлась самостоятельной дисциплиной. Но есть достаточно оснований считать, что мыслители, педагоги, философы и даже государственные деятели в то время начали обращать внимание на язык и письменность. Приведу такие примеры:

\section{$\Delta$ иалектное исследование}

Диалекты постоянно вызывали у императоров повы- шенное внимание в силу того, что реализация административного приказа и связь между центром и местами требовали знание диалектов. По записям «Цзо-чжуань» [1, с.103] режим исследования диалектов был уже установлен в эпоху династии Ся (около 2070 г. до н.э. - около 1600 до н.э.), тогда исследование осуществлялось в форме сбора народных песен. В эпоху правления династий Чжоу и Цинь (1046 г. до н.э. - 206 г. н.э.) ежегодно в августе государственными властями отправлялись послы в разные места для исследования диалектов. Эти ценные диалектологические материалы, сохраненные в домах Чжоу и Цинь, были уничтожены после гибели династии Цинь.

Лексико-семантический анализ. В древней литературе в доциньскую эпоху имеются яркие и точные примеры лексико-семантического анализа, такие как анализ глаголов “伐”, “侵”, “袭”(они синонимичны, у них общее значение: совершать набег), и еще анализ имен существительных “是”, “非”(они антонимы, обозначающие правду и кривду)[2, с.13]. Хотя таких примеров немного, но мы предполагаем, что древние народы Китая были неравнодушный к вопросу семантики.

\section{Разъяснение политических позиший}

Цзи Канцзы (премьер-министр княжества Лу, 491-468 г. до н.э.) спросил у Конфуция о политике, Конфуций ему ответил: “Политика должна быть непорочна и степенна. Кто может быть непорядочным, если вы прежде всего правите своё поведение?" Это также служит примером последующего голосового объяснения (голосовое объяснение - это термин Сюньгусюэ, который объясняет значения иероглифа по его чтению, например, через омонимы). Стоит отметить, что Конфуций и Мэнцзы за- 
нимались голосовым объяснением по причине разъяснения политических позиций, а не с целью развития филологии.

\section{Теория языка}

Когда речь идет о зарождении китайского языкознания, мы не должны забывать философов в доциньскую эпоху, которые выдвигали в своих философских трудах языковые теории, относящиеся к языкознанию. К примеру, Сюньцзы (китайский философ, около 313-215 до н.э.) изложил в литературе «Сюньцзы-выправление имен» [2, c.277] три языковых закона: 1. Язык - это продукт общества. Сюньцзы считает, что наименование вещей является абстрактным, к сути предмета не относится так люди договорились называть тот или иной предмет. 2.Язык характеризуется национальностью, мышление присуще человечеству. Поскольку язык имеет национальный характер, формы и структуры конкретных языков отличаются друг от друга. Поскольку только человечку присуще такие психические функции, как мышление и речь, то посредством перевода люди могут общаться с представителями разных народов. 3.Язык устойчив, при этом он развивается. По мнению Сюньцзы, если бы родился совершенный правитель, он бы наверняка оставил существующую лексику (сохранил ее чистоту и норму) и поддерживал бы создание новой лексики для приспособления к современной жизни. Сюньцзы приписывает сохранение и создание лексики к успехам императоров, это, конечно, неправильно, но его идеи о необходимости сохранения существующих слов и создание новых оправдана.

В общем, языковые исследования в доциньскую эпоху находится на низшей ступени: невозможно расценивать фактические достижения диалектных исследований изза малого количества данных; лексико-семантический анализ был относительно разрознен; разъяснение политических позиций с помощью формы или значения иероглифа проходили не для развития филологии; философы были учёными, которые не рассматривали язык как отдельный научный объект, хотя их языковая теория в доциньскую эпоху была ценной. Поэтому нам следовало бы сказать, что вышеупомянутые исследования находятся в зачаточном состоянии.

\section{Языковые исследования в ханыкую эпоху}

Представители двух династий Хань (ранняя 202г. до н.э. -9г. н.э.; поздняя 252-220г. н.э.) правили более 400 лет. В этот период языкознание было тесно связано с изучением канонических книг. С императора У-ди (156-87г. до н.э.) начали отвергать сто школ, почитать только конфуцианство. Со временем значение изучения канонических книг становилось все выше и выше, и в эпоху династии Восточной Хань (25-220г. н.э.) наступил золотой век изучения книг. Наиболее важными филологическими данными являются: «Диалект» Янсюн, «Шовэнь Цзецзы» Сюйшэнь и «Шимин» Люси. Эти труды имеют эпохальное значение.«Диалект» является фундаментом языковой диалектологии, «Шовэнь Цзецзы» представляет собой квинтэссенцию ханьской иероглифики и лексикологии, «Шимин» - это первый специализированный труд этимологии в Китае. Каждый из трех трудов представляет собой отделение китайской иероглифики и составляется объяснение семантики этих слов. Они отражают основные характеристики языкознания в течение этого периода.

В истории китайского языкознания самым ранним было сюньгусюе. Это соответствует закону развития: характерные пункты китайского языка определили такой путь развития. В Индии приблизительно в $\mathrm{V}$ в. до н.э. была создана такая грамматика санскрита (т.е. грамматика Панини), в которой не нуждался древний Китай, поскольку китайский язык является аналитическим языком, имеющим мало морфологических изменений. Звуки являются составной частью грамматики санскрита, так что древнеиндийская фонетика достигла высокой степени развития. Однако в Китае становление фонетики образовалось позже, чем в Индии, потому что китайская письменность не относится к фонетическому письму. Сюньгусюе, отвечало потребностям общества того времени, поэтому зародилось раньше.

Сюньгусюе в ханьскую эпоху было создано именно потому, что оно имеет тесное отношение с культурным развитием ханьцев. В доциньском обществе людям было трудно достать книги, причем, по причине громоздкости бамбуковых дощечек для письма существовало очень мало книг, переданных с более ранних эпох. Толкование большинства литературных трудов, таких как «Ши»и «Шу», написано не так давно (период враждующих государств находится всего в четырех или пятистах годах от династии Западная Чжоу), и большинство людей до сих пор понимают, поэтому обучение не требуется. В эпоху правления династии Хань были упрощены иероглифы, в частности был создан новый вид китайского древнего письма "Лишу", появилась бумага, выросло количество бамбуковых дощечек для письма и достаточно далеко от времен «Ши», «Шу», «Ли», «И», «Чунь-цю» (система конфуцианского пятикнижия). Таким образом, в то время предлагали учить людей сюньгу через занятия сяосюе, и вот поэтому появилась книга «Эръя». Кроме этого, государство поощряло изучение канонических книг - это также одна из причин создания сюньгусюе.

Исследование диалектологии связано сдолговременным единством государства. Чем дольше государство находится под норной властью, тем больше внимания обращают на сложность диалектов. Но в древне-китайском языкознании диалектология не являлась основной 
тенденцией, более того, в средне-китайском она занимала ещё ниже ступень в силу того, что иероглиф не входит в состав фонетического письма. Различия звучания между диалектами и нормой не оказывали влияние на письменный язык. Кроме диалектных слов, употребляемых в обычном языке, остальные слова обычно не записывались, так что люди тогда редко интересовались диалектными словами.

Выпуск словаря китайских иероглифов являлась высшей точкой китайского языкознания в ту эпоху. Почему только до середины эпохи правления династии Восточной Хань (25-220г. н.э.) достигли этой вершины? Во-первых, любое академическое развитие подразумевает время и процесс; во-вторых, по мере того, как "лишу" пользовалось популярностью, форма иероглифа сильно изменилась, поэтому не смогли определить собственную форму некоторых иероглифов и понять их значения; в-третьих, со временем древнее значение ие- роглифа стало всё более трудным для понимания, только по толкованию древних текстов уже невозможно решить вопрос.[4, с.24-45] Если бы не было Сюйшень, всё равно появился бы такой словарь. Но создание такого высококачественного словаря как «Шовэнь Цзецзы» относится к успехам Сюйшень. Его большой успех заключается в появлении ключей. По сути иероглиф выражает значение по его форме. С одной стороны, поняв форму иероглифа, у нас есть шанс определить его основное значение (т.е. основное значение слов), с другой стороны, поняв основное значение иероглифа, мы можем исправить неправильное написание. Словарь «Шовэнь Цзецзы» сильно повлиял на дальнейшее развитие филологии, словари последующих поколений следуют структуре «Шовэнь Цзецзы», просто увеличивается количество слов и добавляются примеры. Словарь «Шовэнь Цзецзы» является сокровищем китайского исторического языкознания, ценность которого до сих пор велика.

\section{ЛИТЕРАТУРА}

1. Цзо Цюмин, Хунфэн. Цзо-чжуань //Пекин: Издательство ВАРЛИ, 2016.-С.103.

2. Фан Юн, Ли Бо. Сюнь-цзы//П.: Китайское книгоиздательство,2011.-С.13, С.277.

3. Сюй Шень, Тан Кэцзин. Словарь Шовэнь Цзецзы//П.: Китайское книгоиздательство, 2018.

4. Ван Ли. История китайского языкознания//Шанхай: Издательство фуданьского университета, 2018. - С.24-45.

5. Хэ Цзюин. История китайского традиционного языкознания//П.: Коммерческое издательство, 2017. 